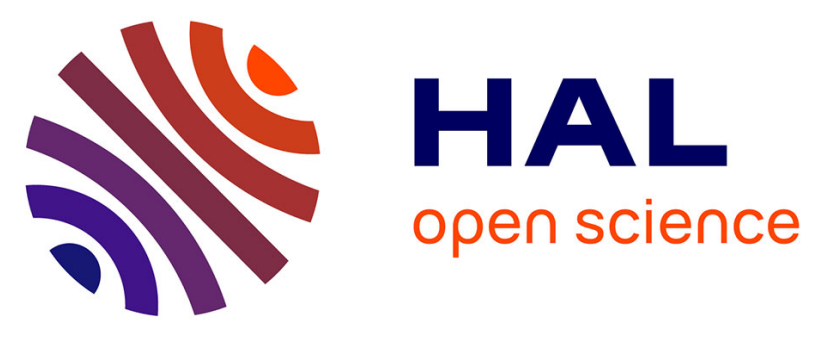

\title{
Cyclophilin-Facilitated Membrane Translocation as Pharmacological Target to Prevent Intoxication of Mammalian Cells by Binary Clostridial Actin ADP-Ribosylated Toxins
}

Katharina Ernst, Simon Langer, Eva Kaiser, Christian Osseforth, Jens Michaelis, Michel Popoff, Carsten Schwan, Klaus Aktories, Viktoria Kahlert, Miroslav Malesevic, et al.

\section{- To cite this version:}

Katharina Ernst, Simon Langer, Eva Kaiser, Christian Osseforth, Jens Michaelis, et al.. CyclophilinFacilitated Membrane Translocation as Pharmacological Target to Prevent Intoxication of Mammalian Cells by Binary Clostridial Actin ADP-Ribosylated Toxins. Journal of Molecular Biology, 2015, 427 (6), pp.1224 - 1238. 10.1016/j.jmb.2014.07.013 . pasteur-01768428

\section{HAL Id: pasteur-01768428}

https://hal-pasteur.archives-ouvertes.fr/pasteur-01768428

Submitted on 31 Jul 2018

HAL is a multi-disciplinary open access archive for the deposit and dissemination of scientific research documents, whether they are published or not. The documents may come from teaching and research institutions in France or abroad, or from public or private research centers.
L'archive ouverte pluridisciplinaire HAL, est destinée au dépôt et à la diffusion de documents scientifiques de niveau recherche, publiés ou non, émanant des établissements d'enseignement et de recherche français ou étrangers, des laboratoires publics ou privés.

\section{(1)(1) $\$(0)$}

Distributed under a Creative Commons Attribution - NonCommercial - ShareAlikel 4.0 


\section{Cyclophilin-facilitated membrane translocation as pharmacological target to prevent intoxication of mammalian cells by binary clostridial actin ADP-ribosylated toxins}

Katharina Ernst ${ }^{1}$, Simon Langer ${ }^{1}$, Christian Osseforth ${ }^{2}$, Jens Michaelis ${ }^{2}$, Michel R. Popoff ${ }^{3}$, Carsten Schwan ${ }^{4}$, Klaus Aktories ${ }^{4}$, Gunter Fischer ${ }^{5}$, Cordelia Schiene Fischer ${ }^{5}$, and Holger Barth $^{1 *}$

${ }^{1}$ Institute of Pharmacology and Toxicology, University of Ulm Medical Center, Ulm, Germany

${ }^{2}$ Institute of Biophysics, University of Ulm, Germany

${ }^{3}$ Department of Anaerobic Bacteria, Pasteur Institute, Paris, France

${ }^{4}$ Institute of Experimental and Clinical Pharmacology and Toxicology, University of Freiburg, Freiburg, Germany

${ }^{5}$ Max Planck Research Unit for Enzymology of Protein Folding Halle, Halle, Germany

Running Title: Cyclophilins in membrane transport of actin ADP-ribosylating toxins

${ }^{\dagger}$ This work was financially supported by the Deutsche Forschungsgemeinschaft (grant to H.B. BA 2087/2-2).

*Correspondent footnote:

Dr. Holger Barth

Institute of Pharmacology and Toxicology, University of Ulm Medical Center

Albert-Einstein-Allee 11, D-89081 Ulm, Germany 
Tel.: 49-731-50065503, Fax: 49-731-50065502

E-mail: holger.barth@uni-ulm.de

and

Dr. Cordelia Schiene-Fischer 


\section{Abstract}

The binary enterotoxins Clostridium (C.) botulinum $\mathrm{C} 2$ toxin, $C$. perfringens iota toxin and $C$. difficile CDT belong to the family of binary actin ADP-ribosylating toxins. They are composed of a binding/translocation component and a separate enzyme component. The enzyme components mono-ADP-ribosylate G-actin in the cytosol of target cells resulting in depolymerization of F-actin, cell rounding, and eventually cell death. The transport of the enzyme components into the cytosol is mediated by the binding/translocation components which bind to their cellular receptors and form complexes with the respective enzyme components. After receptor-mediated endocytosis, the binding/translocation components form trans-membrane pores into the membranes of acidified endosomes. The enzyme components translocate through these pores from the endosomal lumen into the cytosol which is facilitated by host cell chaperones including the heat shock protein (Hsp) 90 and peptidyl-prolyl cis/trans isomerases (PPIases) comprising cyclophilin A and FK506 binding protein 51. These factors interact with the enzyme components in vitro and in intact cells and their pharmacological inhibition prevents the membrane transport of the latters.

Here, we demonstrate that cyclophilin-40 binds to the enzyme components of C2, iota and CDT toxins in vitro. More detailed characterization of the interaction between cyclophilin-40 and C2I, the enzyme component of $\mathrm{C} 2$ toxin by dot blotting and isothermal titration calorimetry (ITC) analysis revealed a direct binding of C2I to cyclophilin-40 with a calculated affinity of ......The interaction did not depend on the ADP-ribosyltransferase activity of C2I as tested with enzymatic inactive C2I protein, but was evidently stronger for unfolded C2I. The interaction of C2I with cyclophilin-40 was also demonstrated in intact C2 toxin-treated cells by pull-down assay. Treatment of mammalian cells with a non-immunosuppressive cyclosporine A (CsA) derivative, which inhibits the PPIase activity of cyclophilins, protects cells from 
intoxication with $\mathrm{C} 2$ and iota toxins, offering an attractive approach for development of novel therapeutic strategies against this toxin family.

\section{Introduction}

Various clostridia produce potent exotoxins, which mono-ADP-ribosylate G-actin at arginine177 in the cytosol of mammalian target cells (for review see (Barth, Aktories et al, 2004)). This toxin-catalyzed modification turns G-actin into a capping molecule which prevents further polymerization of actin filaments (Aktories, Bärmann, 1986; Ohishi and Tsuyama, 1986; Vandekerckhove, J., Schering, B., 1987; Vandekerckhove, J., Schering, B., 1988) and results in the breakdown of the actin cytoskeleton. Finally, the mode of action of these toxins results in cell-rounding (Aktories and Wegner, 1989; Wegner and Aktories, 1988; Weigt et al, 1989; Wiegers et al, 1991; Miyake and Ohishi, 1987; Ohishi et al., 1980) and cell death (Heine et al, 2008; Hilger et al, 2009) associated with severe enteric diseases in humans and animals (Ohishi, 1983; Ohishi and Odagiri, 1984; Songer, 1996; Geric et al, 2004; McDonald et al., 2005). Binary actin-ADP-ribosylating toxins are the $\mathrm{C} 2$ toxin from $C$. botulinum, the prototype of this toxin family (Ohishi et al., 1980), and the iota-like toxins which comprise the iota toxin from C. perfringens type E strains (Stiles and Wilkins, 1986a; Stiles and Wilkins, 1986b), CDT from hypervirulent strains of $C$. difficile (Perelle et al, 1997a; Popoff et al, 1988; Stubbs et al, 2000; Gülke et al, 2001) and the C. spiroforme transferase (CST) (Popoff and Boquet, 1988). The iota-like toxins are closer related among each other than to $\mathrm{C} 2$ toxin regarding their degree of sequence homology (Perelle et al, 1997b), the interchangeability of their components and the modification of actin isoforms which serve as a substrate (for review see (Barth et al, 2004)). Moreover, all iota-like toxins bind to the lipolysis-stimulated receptor (LSR) on particular target cells (Paptheodorou et al, 2012; Papatheodorou et al., 2013) while C2 toxin binds to a 
carbohydrate receptor which is present on all mammalian cell types tested so far (Eckhardt et al, 2002).

However, C2 toxin and the iota-like toxins share an overall comparable unique structure and mode of action. They are composed of two non-linked proteins, an enzyme (A-) component and a separate binding and translocation (B-) component. Both components must assemble on the surface of target cells where the B-component binds to its cellular receptor, forms a complex with the A-component, and facilitates the receptor-mediated endocytosis and subsequently the transport of the A-component from acidified endosomal vesicles into the cytosol (for review see (Barth et al, 2004)). The cellular uptake of $\mathrm{C} 2$ and iota toxins was discovered by us and others during recent years. C2 toxin consists of the enzyme component C2I ( $\sim 49 \mathrm{kDa})$ (Fujii et al, 1996; Barth et al, 1998) and the binding/translocation component C2II ( $~ 80$ or $100 \mathrm{kDa}$, depending on the strain (Barth et al, 2000; Sterthoff et al, 2010). Proteolytically activated C2II forms ring-shaped heptamers (C2IIa) that bind to asparagine-linked carbohydrate structures on mammalian cells (Barth et al, 2000; Blöcker et al, 2000; Eckhardt et al, 2000; Stiles et al, 2002; Schleberger et al, 2006) and form complexes with C2I. After their receptor-mediated endocytosis, the $\mathrm{C} 2 \mathrm{IIa} / \mathrm{C} 2 \mathrm{I}$ complexes reach early endosomal vesicles where the C2IIa heptamers change their conformation, insert as pores into endosomal membranes and serve as channels for translocation of unfolded C2I from the endosomal lumen into the cytosol (Schmid et al, 1994; Barth et al, 2000; Bachmeyer et al, 2001; Blöcker et al, 2003a; Blöcker et al, 2003b). The cellular uptake and intracellular membrane transport of iota toxin is widely comparable (Blöcker et al, 2001). After receptor-mediated endocytosis of the Ib/Ia complexes, the proteolytically activated binding/translocation component $\mathrm{Ib}$ also forms heptameric transmembrane pores, which mediate translocation of the enzyme component Ia $(47 \mathrm{kDa})$ across endosomal membranes into the cytosol (Stiles et al, 2002; Knapp et al, 2002; Blöcker et al, 2001; Nagahama et al, 2002; Hale et al, 2004). However, there are some differences during cellular uptake of C2 toxin and iota toxin since Ia likely translocates from endosomes, which 
are in a state between early and late endosomes (Gibert et al, 2007), while C2I translocates from early endosomes (Barth et al, 2000). Most likely, translocation of Ia requires more acidic conditions and a membrane potential gradient in addition to the $\mathrm{pH}$ gradient (Gibert et al, 2007). Despite these differences, membrane translocation of $\mathrm{C} 2$ toxin and iota toxin is facilitated by the same chaperones including heat shock protein (Hsp) 90 (Haug et al, 2004; Haug et al, 2005) and the peptidyl-prolyl cis/trans isomerases (PPIase) cyclophilin (Cyp) A (Kaiser et al, 2009; Kaiser et al., 2011) and FK506 binding protein (FKBP) 51 (Kaiser et al, 2012). Moreover, these host cell factors are also involved in membrane translocation of $C$. difficile CDT and we have got evidence that the Hsp90/PPIase-mediated membrane transport might be a common feature of bacterial ADP-ribosylating toxins (Kaiser et al, 2012). PPIases are protein folding helper enzymes which catalyze the cis-trans isomerization of proline-peptide bonds, which often represents a rate-limiting step during protein refolding even after membrane transport of proteins (Bang and Fischer, 1991; Fischer et al, 1989; Schmid 1993; Schmid et al, 1993; Galat 2003).

Pharmacological inhibition of the PPIase activity of Cyps in cultured cells by cyclosporine A (CsA) (Handschumacher et al, 1984; Fanghänel and Fischer, 2003) protected cells from intoxication with $\mathrm{C} 2$, iota and CDT toxins because the intracellular membrane transport of the enzyme components of these toxins was inhibited (Kaiser et al, 2009; Kaiser et al., 2011), indicating that Cyps are crucial for this step. Prompted by this observation we demonstrated earlier that CypA interacts with C2I in vitro and in intact cells (Kaiser et al, 2009) and inhibition of CypA prevented translocation of C2I from endosomal vesicles to the cytosol in vitro (Kaiser et al, 2009).

Here, we report that Cyp40 binds to C2I in vitro and in intact cells and characterize this interaction by dot blot and isothermal titration calorimetric analysis in more detail. Cyp40 also interacts with the enzyme components of iota-toxin and CDT, suggesting a common principle 
for this toxin family. Since Cyps are crucial for uptake of binary actin ADP-ribosylating toxins into the cytosol of mammalian cells, we tested whether a non-immunosuppressive CsAderivative protects cells from intoxication, which might be an attractive pharmacological option against the members of this toxin family.

\section{Materials \& Methods}

\section{Materials}

MEM (cell culture medium) and fetal calf serum were acquired from Invitrogen (Karlsruhe, Germany). Materials for cell culture were purchased from TPP (Trasadingen, Switzerland). Complete ${ }^{\circledR}$ protease inhibitor and streptavidin-peroxidase were obtained from Roche (Mannheim, Germany). Protein molecular weight marker Page Ruler prestained protein ladder was acquired from Thermo scientific (Bonn, Germany). Biotin-labeled NAD ${ }^{+}$was purchased from R\&D Systems GmbH (Wiesbaden-Nordenstadt, Germany). Baf A1 was obtained from Calbiochem (Bad Soden, Germany) and CsA from Fluka (Munich, Germany). Enhanced chemiluminescence (ECL) system was acquired from Millipore (Schwalbach, Germany). The EZ-Link sulfo-NHS-Biotin and the streptavidin-sepharose beads were from Pierce (Bonn, Germany). Illustra MicroSpin G-25 Columns were from GE Healthcare (Munich, Germany) and Micro Bio-SpinTM Chromatography Columns were from Bio-Rad (Munich, Germany). Atto-590-NHS-Ester was from Atto-Tec (Siegen, Germany).

Synthese VK112-2 und MM284?--> Cordelia

\section{Protein expression and purification}


Human FKBP12 was expressed using pET28a (Novagen, Darmstadt, Germany) in Escherichia coli Rosetta cells and purified according to published procedures (Edlich et al., 2006). Cyp40 .......-->Cordelia

The recombinant C2I, C2IE387/389Q and C2IIa proteins were purified and activated as described before (Barth et al., 1998; 2000). Recombinant C3bot was purified as described earlier (Fahrer et al., 2010). Ia and Ib were prepared as described earlier (Perelle et al., 1996). Recombinant CDTa (from $C$. difficile strain 196) was produced and purified as a His-tagged protein in the Bacillus megaterium expression system as described earlier (Papatheodorou et al., 2010).

\section{Cell culture and cytotoxicity assays}

Vero (African green monkey kidney) and HeLa cells were cultivated in MEM containing 10\% heat-inactivated fetal calf serum (FCS), $1.5 \mathrm{~g} / 1$ sodium bicarbonate, $1 \mathrm{mM}$ sodium-pyruvate, $2 \mathrm{mM}$ L-glutamine and $0.1 \mathrm{mM}$ non-essential amino acids at $37{ }^{\circ} \mathrm{C}$ and $5 \% \mathrm{CO}_{2}$. Cells were detached using trypsin and reseeded no more than 20 times. For cytotoxicity assays, cells were seeded in culture dishes and incubated in MEM plus FCS with the respective toxin. To inhibit the PPIase activity of Cyps the cells were pre-incubated with indicated concentrations of CsA or the non-immunosuppressive CsA-derivative VK112-2 for 30 min and these inhibitors were present in the medium during the further incubation of the cells with the toxin. Cells were visualized after the indicated incubation times by using a Zeiss Axiovert 40CFI microscope (Oberkochen, Germany) with a Jenoptik progress C10 CCD camera (Jena, Germany). The toxin-induced changes in cell morphology (i.e. cell-rounding) were analyzed and percentage of round cells was determined from the images as described earlier (Kaiser et al, 2009). 


\section{Toxin translocation assay with intact cells}

The $\mathrm{pH}$-dependent translocation of C2I through C2IIa pores across the endosomal membrane was experimentally mimicked at the cytoplasmic membrane of intact Vero cells as described earlier (Barth et al, 2000). In brief, Vero cells were cooled to $4{ }^{\circ} \mathrm{C}$ and $\mathrm{C} 2$ toxin was added. After a binding period of $15 \mathrm{~min}$, an acidic pulse was given ( $\mathrm{pH} 4.6$ ). Under the acidic conditions C2IIa forms pores into the cytoplasmic membrane and C2I translocates directly into the cytosol. Cell rounding was monitored and visualized by photography.

\section{STED -> Christian Osseforth Biophysik}

\section{Interaction analysis between C2I and immobilized Cyp40 using the dot blot system}

Serial dilutions of the purified proteins Cyp40, FKBP12 and C3bot were vacuum aspirated onto a nitrocellulose membrane using the Bio-Rad dot blot system (Munich, Germany) according to the manufacturer's manual. A Ponceau S staining was performed and then the membrane was blocked with $5 \%$ non-fat dry milk in PBS containing $0.1 \%$ Tween-20 (PBST). Subsequently, the membrane was cut and probed with the respective overlay proteins $(200 \mathrm{ng} / \mathrm{ml})$ for $1 \mathrm{~h}$. After extensive washing, the bound proteins were detected by streptavidin-peroxidase (biotinlabeled overlay proteins) or a specific antibody against C2I and a peroxidase-coupled anti-rabbit antibody from Santa Cruz (Heidelberg, Germany) by using the ECL system. To investigate the binding of unfolded C2I, CDTa and Ia to immobilized Cyp40 the biotin-labeled enzyme components were incubated with $6 \mathrm{M}$ guanidine hydrochloride, $2 \mathrm{mM}$ DTT, $30 \mathrm{mM}$ TrisHCl or with PBS for control for $1 \mathrm{~h}$ before they were tested in the dot blot assay as described before. To confirm that this procedure results in denatured C2I, CDTa and Ia, in vitro ADP-ribosylation of actin was tested as described below. 
ITC -> Cordelia

\section{Pull-down experiments with GST-C2I and biotin-C2I}

The pull-down experiments were performed as described earlier (Kaiser et al, 2009; Kaiser et al, 2012). In brief, HeLa cells were grown in $10 \mathrm{~cm}$ dishes and incubated in serum-free MEM at $37^{\circ} \mathrm{C}$ for $2 \mathrm{~h}$ with biotin-C2I $(400 \mathrm{ng} / \mathrm{ml})$ plus C2IIa $(800 \mathrm{ng} / \mathrm{ml})$ or for control without toxin. Subsequently, cells were lysed using an $18 \mathrm{G}$ needle-syringe, the cytoplasmic fraction was obtained by centrifugation and subsequently incubated with a $60 \mu 1$ bed volume (1:1 in PBS) of streptavidin-sepharose beads overnight at $4^{\circ} \mathrm{C}$. As an alternative approach, GST-C2I was applied instead of biotin-C2I and glutathione-sepharose beads were used in place of streptavidin-sepharose beads for pull-down of GST-C2I. The precipitated proteins were washed, subjected to SDS-PAGE and the proteins were transferred onto a nitrocellulose membrane that was probed with a specific antibody against Cyp40 from Thermo Fisher (Bonn, Germany). After incubation with a secondary peroxidase-coupled anti-rabbit antibody the coprecipitated Cyp40 was visualized using the ECL system.

\section{Reproducibility of the experiments and statistics}

All experiments were performed independently at least two times. Results from representative experiments are shown in the figures. In each individual Western blot panel shown in the figures, the protein bands were originally detected on the same membrane and cut out and recombined for presentation only in the figures. Values $(n \geq 3)$ are calculated as mean \pm standard deviation (SD) using the Prism4 Software (GraphPad Software). 


\section{Results}

CsA alters the intracellular distribution of the enzyme component C2I of C. botulinum C2 toxin in HeLa cells - Initially, we investigated the effect of the specific pharmacological inhibitor CsA which blocks the activity of PPIases on the intracellular distribution of the enzyme component $\mathrm{C} 2 \mathrm{I}$ of the $\mathrm{C} 2$ toxin. To this end, we used confocal as well as stimulated emission depletion (STED) microscopy for super resolution imaging. HeLa cells were pre-treated with CsA and subsequently the fluorescence-labeled enzyme component C2I plus the transport component C2IIa were added. After $2 \mathrm{~h}$ cells were fixed and bright-field, confocal and STED microscopy images taken. The characteristic morphology of $\mathrm{C} 2$ toxin-treated cells is shown in the overview in Fig. 1 in the upper panel. Cells treated with $\mathrm{C} 2$ toxin alone rounded up within $2 \mathrm{~h}$ due to the destruction of the actin cytoskeleton caused by the enzymatic activity of C2I. In the presence of CsA, the number of rounded cells was significantly reduced as demonstrated earlier (Kaiser et al, 2009). Next, the distribution of C2I in these cells was analyzed by confocal (Fig.1 middle panel) and in more detail by STED microscopy (Fig. 1 lower panel). In CsAtreated cells there was a more punctured and less diffuse distribution of C2I compared to cells treated with C2 toxin alone. Pre-treatment of cells with bafilomycin A1 (BafA1) which prevents acidification of early endosomes thereby trapping C2I in these vesicles, resulted in an overall comparable cellular distribution of C2I as found in cells treated with $\mathrm{C} 2$ toxin in the presence of CsA. Furthermore, the images demonstrate that CsA and BafA1 did not interfere with early steps of toxin uptake like receptor-binding or receptor-mediated endocytosis since C2I was detectable in the cells. Taken together, the microscopic analysis suggests that less C2I translocates into the cytosol of CsA-treated cells which is in line with our earlier results obtained by biochemical approaches (Kaiser et al, 2009). 
Cyp40 co-precipitates with C2I in lysates from C2 toxin-treated cells -HeLa cells were incubated with GST-C2I plus C2IIa or left untreated for control. Subsequently, cells were lysed and lysates incubated with glutathion-sepharose beads to pull-down GST-C2I and associated proteins. Co-precipitated Cyp40 was analyzed by Western blotting with a specific antibody. As shown in Fig 2A, Cyp40 was detected in precipitates from HeLa cells treated with GST-C2I plus C2IIa prior to lysis but not in the precipitates from untreated cells, indicating that Cyp40 interacts with GST-C2I. To ensure that the GST-tag had no effect on this interaction, the experiment was repeated with biotin-C2I instead of GST-C2I. As shown in Fig. 2B, a comparable result was obtained, clearly indicating that Cyp40 specifically interacted with $\mathrm{C} 2 \mathrm{I}$ in intact cells.

C2I, CDTa and Ia directly interact with Cyp40 in vitro - From the pull-down experiments it could not be concluded whether C2I directly interacts with Cyp40 or whether other proteins might serve as an adaptor for this interaction. Therefore, dot blot analysis was performed to test whether C2I directly binds to Cy40 in vitro. Purified recombinant Cyp40 was spotted onto a nitrocellulose membrane followed by overlay with biotin-labeled C2I. The result shown in Fig 3A revealed a direct interaction between Cyp40 and C2I. This interaction was specific since biotin-C2I did not bind to the non-relevant $\mathrm{C} 3$ bot protein or to the membrane and there was no signal when the overlay buffer was applied instead of biotin-C2I (Fig. 3A). Comparable results were obtained when CDTa and Ia where analyzed instead of C2I, clearly indicating that Cyp40 directly interacts with the enzyme components of $\mathrm{C} 2$ toxin and of the iota-like toxins in vitro. Prompted by this finding, we next investigated whether this interaction depends on the enzyme activity of the toxins and analyzed the enzymatically inactive C2IE387/389Q (Barth 1998) in parallel to C2I. The signal of bound protein was comparable for the mutant and the wild-type 
C2I, indicating that the loss of enzyme activity does not interfere with binding of C2I to Cyp40 (Fig 3 B).

However, pre-treatment of C2I, CDTa and Ia by guanidine hydrochloride dramatically enhanced the binding of these proteins to Cyp40 in vitro (Fig. 3C), strongly suggesting that the interaction with Cyp40 preferentially occurs in the unfolded conformation of the enzyme components. The difference in binding affinity of unfolded CDTa and Ia was so strong that detection of both signals, unfolded and native, during the same exposure time was difficult. Respective binding of the native CDTa and Ia was confirmed by longer exposure times (not shown). The denaturing effect of guanidine hydrochloride-treatment on the enzyme components of the toxins was confirmed by in vitro ADP-ribosylation of actin (not shown).

Quantitative analysis of the interaction between Cyp40 and C2I by ITC - The interaction between Cyp40 and C2I was analyzed in more detail by ITC $\rightarrow$ Cordelia

The intoxication of Vero cells with $C 2$ toxin and iota toxin is inhibited by the nonimmunosuppressive CsA derivative VK112-2 - Finally, we tested whether the nonimmunsosuppressive CsA-derivative VK112/2 also protects cells from intoxication with C2 toxin and iota toxin. To this end, Vero cells pre-treated with increasing concentrations of VK112/2 or with CsA for control were challenged with either C2 toxin or iota toxinand cellrounding was analyzed (Fig. 5). Although less efficient compared to CsA, pre-treatment of cells with VK112/2 significantly delayed the toxin-induced cell-rounding in a time- and concentration-dependent manner, indicating that VK112/2 also interferes with mode of action of the toxins. Treatment of cells with VK112/2 alone had no effect on cell morphology (Fig. 5A). Noteworthy, pre-treatment of cells with the non-cellpermeable CsA-derivative MM284 
had no inhibiting effect on intoxication with $\mathrm{C} 2$ or iota toxin (Fig. 5C). Moreover, pre-treatment with this compound inhibited the $\mathrm{pH}-$ driven translocation of cell-bound $\mathrm{C} 2$ toxin across the cytoplasmic membrane of intact cells (Fig. 6), implicating that VK112/2 inhibits the translocation of C2I from the lumen of acidic endosomes into the host cell cytosol and thus interferes with exactly the same step during toxin uptake into cells as CsA. This is a wellestablished approach in the field of toxin research to mimic the situation in the lumen of acidified endosomal vesicles directly on the surface of living cells which was used to characterize the molecular mechanisms underlying membrane translocation of various bacterial protein toxins (Sandvig and Olsnes, 1980) including C2, iota and CDT toxins in vitro (Barth et al, 2000, Blöcker et al, 2001, Kaiser et al, 2011). In summary, prompted by our earlier findings that the PPIase activity of Cyps facilitates membrane translocation of clostridial binary actin ADP-ribosylating toxins, Cyp40 was identified as a new binding partner for the enzyme components of $\mathrm{C} 2$, iota and CDT toxins and the protective effects of a non-immunosuppressive CsA-derivative against these toxins established in a cell model. 


\section{Discussion}

The results described in this article are an extension of our ongoing research on the role of host cell chaperones/PPIases for membrane translocation of bacterial protein toxins. In summary, we discovered that besides Hsp90 the PPIase activity of cyclophilin(s) and FKBP(s) facilitates the membrane translocation of clostridial actin ADP-ribosylating toxins $\mathrm{C} 2$, iota and CDT from acidic endosomes into the cytosol, and demonstrated that pharmacological inhibition of Hsp90, Cyps or FKBPs prevents toxin translocation and thereby intoxication of cultured cells with $\mathrm{C} 2$ toxin, iota toxin and CDT. In contrast, the membrane translocation of bacterial toxins, which deliver their enzyme moieties also from acidic endosomes into the cytosol but are not ADPribosyltransferases, does not require Hsp90 and the PPIases. In conclusion, the results implicate a common Hsp90/Cyp/FKBP-dependent membrane translocation mechanism, which is selective for ADP-ribosylating toxins.

In vitro, purified recombinant Hsp90, CypA and FKBP51 directly bound to the enzyme components of the binary actin ADP-ribosylating toxins and for the prototype of this family, $\mathrm{C} 2$ toxin, the interaction between the enzyme component $\mathrm{C} 2 \mathrm{I}$ and these factors was demonstrated in intact cells by pull-down experiments. However, we could not exclude that further Cyps besides CypA also interact with C2I since the pharmacological inhibitor CsA is not selective for CypA. Recently, by using the actin-ADP-ribosylating Photorhabdus luminescence toxin TccC3, we could show for the first time that besides Hsp90, CypA and FKBP51, also Cyp40 interacts with the isolated ADP-ribosyltransferase domain of this toxin in intact cells. This was an interesting finding since the PPIase activity of Cyp40 is inhibited by CsA and Cyp40 is part of a multi-chaperone complex that contains Hsp90 and FKBP51, both binding partners of the enzyme components of the binary actin ADP-ribosylating toxins, C2I, Ia and CDTa. In cells, this multi-chaperone complex mediates the membrane translocation of the steroid hormone receptor across the nuclear membrane. Moreover, another Hsp90containing translocation factor complex facilitates the translocation of diphtheria toxin (DT), 
another ADP-ribosylating bacterial toxin, from acidified endosomal vesicles into the cytosol in vitro, as discovered earlier by Ratts and co-workers. We found previously that the membrane translocation of DTA, the enzyme domain of DT, also requires the PPIase activity of Cyp(s) and showed the direct interaction between DTA and recombinant CypA in vitro. However, it is not known so far whether PPIases are part of the translocation complex.

Therefore, we investigated whether C2I and the enzyme components of the iota-like toxins interact with Cyp40. Here, we demonstrated by dot blot analysis that C2I, Ia and CDTa directly bind to Cyp40 in vitro and characterized this interaction in more detail for the prototype C2I. The ADP-ribosyltransferase activity of C2I is not essential for the binding to Cyp40 in vitro, which is in line with our earlier result obtained for DTA and CypA. However, treatment of C2I with guanidine hydrochloride, which results in loss of its enzyme activity indicating the unfolding of C2I, dramatically increased the binding of C2I to Cyp40 in vitro and comparable results were obtained for Ia and CDTa. This finding strongly suggests that Cyp40 shows preferred interaction with the enzyme components of the binary actin ADP-ribosylating toxins in their unfolded conformation, which is plausible since they unfold, at least partially, during translocation across endosomal membranes through the trans-membrane pores formed by the separate binding/translocation components of these toxins. However, from the pull-down experiments performed in this study, it can not be concluded whether the interaction between C2I and Cyp40 in intact cells is direct or whether Cyp40 is part of a protein complex, such as a Hsp90-multi-chaperone complex, which binds to C2I. Therefore, the logical next steps will be the closer investigation of the interaction between the enzyme components of these toxins with Hsp90 and the PPIases during their membrane translocation in living cells and to test whether Cyp40 interacts with the enzyme moieties of other clinically relevant ADP-ribosyltransferases including diphtheria toxin.

The finding that Cyps are crucial for the uptake of the medically relevant group of bacterial ADP-ribosylating exotoxins including CDT, which is associated with severe forms of $C$. 
difficile-associated pseudomembranous colitis, should also be of clinical interest. Cyps might serve as novel drug targets to prevent the uptake of the toxins into their human and/or animal target cells, which protects cells from intoxication. Since the toxin-induced cell damage represents the reason for the clinical symptoms of the toxin-associated diseases caused by the pathogenic bacteria, pharmacological inhibitors of PPIases such as CsA, could be considered for treatment and/or prevention of such diseases. This might in particular be attractive for diseases caused by toxin-producing bacteria which became (multi-)resistant against our common antibiotics. However, CsA is an immunosuppressive drug and might not be indicated during bacterial infections, but non-imunosuppressive CsA-derivatives such as VK112/2 used in the cell-based experiments of this study might be an alternative and should be tested in animal models.

\section{Acknowledgements}

This work was financially supported by the Deutsche Forschungsgemeinschaft DFG (grant BA 2087/22 to H.B.). K.E. is a fellow of the International Graduate School in Molecular Medicine Ulm (IGradU). We thank Ulrike Binder for excellent technical assistance. 


\section{References}

Aktories, K., Bärmann, M., Ohishi, I., Tsuyama, S., Jakobs, K. H., and Habermann E. (1986). Botulinum C2 toxin ADP-ribosylates actin. Nature 322, 390-392.

Aktories, K., Wegner, A. (1989). ADP-ribosylation of actin by clostridial toxins. J. Cell Biol. 109, 1385-1387.

Bachmeyer, C., Benz, R., Barth, H., Aktories, K., Gilbert, M., and Popoff, M. R. (2001). Interaction of C2 toxin with lipid bilayer membranes and Vero cells: inhibition of channel function by chloroquine and related compounds in vitro and intoxification in vivo. FASEB J. 15, 1658-1660.

Bang, H. and Fischer, G. (1991). Slow conformational changes in protein folding can be accelerated by enzymes. Biomed.Biochim.Acta 50, 137-142.

Barth, H., Aktories, K., Popoff, M.R., Stiles, B. G. (2004) Binary bacterial toxins: biochemistry, biology, and applications of common Clostridium and Bacillus proteins. Microbiol. Mol. Biol. Rev. 8, 373-402.

Barth, H., Preiss, J. C., Hofmann, F. and Aktories, K. (1998). Characterization of the catalytic site of the ADPribosyltransferase Clostridium botulinum C2 toxin by site-directed mutagenesis. J. Biol. Chem. 273, $29506-29511$.

Barth, H., Blöcker D., Behlke, J., Bergsma-Schutter, W., Brisson, A., Benz, R., and Aktories, K. (2000). Cellular uptake of Clostridium botulinum C2 toxin requires oligomerization and acidification. J.Biol.Chem. 275, 1870418711.

Blöcker, D., Barth, H., Maier, E., Benz, R., Barbieri, J. T., and Aktories, K. (2000). The C terminus of component C2II of Clostridium botulinum C2 toxin is essential for receptor binding. Infect. Immun. 68, 4566-4573.

Blöcker, D., Behlke, J., Aktories, K., and Barth, H. (2001). Cellular uptake of the binary Clostridium perfringens iota-toxin. Infect.Immun. 69, 2980-2987.

Blöcker, D., Pohlmann, K., Haug, G., Bachmeyer, C., Benz, R., Aktories, K. and Barth, H. (2003a). Clostridium botulinum $\mathrm{C} 2$ toxin: low $\mathrm{pH}$-induced pore formation is required for translocation of the enzyme component $\mathrm{C} 2 \mathrm{I}$ into the cytosol of host cells. J.Biol.Chem. 278, 37360-37367.

Blöcker, D., Bachmeyer, C., Benz, R., Aktories, K., Barth, H. (2003b). Channel formation by the binding component of Clostridium botulinum $\mathrm{C} 2$ toxin: glutamate 307 of $\mathrm{C} 2 \mathrm{II}$ affects channel properties in vitro and $\mathrm{pH}$ dependent C2I translocation in vivo. Biochemistry. 42, 5368-5377. 
Dmochewitz, L., Lillich, M., Kaiser, E., Jennings, L. D., Lang, A. E., Buchner, J., Fischer, G., Aktories, K., Collier, R. J., and Barth, H. (2011). Role of CypA and Hsp90 in membrane translocation mediated by anthrax protective antigen. Cell Microbiol. 13, 359-373.

Eckhardt, M., Barth, H., Blöcker, D., and Aktories, K. (2000). Binding of Clostridium botulinum C2 toxin to asparagine-linked complex and hybrid carbohydrates. J. Biol. Chem. 275, 2328-2334.

Fahrer, J., Kuban, J., Heine, K., Rupps, G., Kaiser, E., Felder, E., Benz, R., and Barth, H. (2010) Selective and specific internalization of clostridial C3 ADP-ribosyltransferases into macrophages and monocytes. Cell Microbiol. 12, 233-247.

Fanghänel, J. and Fischer G. (2003). Thermodynamic characterization of the interaction of human cyclophilin 18 with cyclosporin A. Biophys.Chem. 100, 351-366.

Fischer, G., Wittmann-Liebold, B., Lang, K., Kiefhaber, T. and Schmid, F. X. (1989). Cyclophilin and peptidylprolyl cis-trans isomerase are probably identical proteins. Nature 337, 476-478.

Fujii, N., Kubota, T., Shirakawa, S., Kimura, K., Ohishi, I., Moriishi, K., Isogai, E., and Isogai, H. (1996). Characterization of component-I gene of botulinum $\mathrm{C} 2$ toxin and PCR detection of its gene in clostridial species. Biochem. Biophys. Res. Commun. 220, 353-359.

Galat, A. (2003). Peptidylprolyl cis/trans isomerases (immunophilins): biological diversity--targets--functions. Curr.Top.Med.Chem. 3, 1315-1347.

Geric, B., Rupnik, M., Gerding, D. N., Grabnar, M. and Johnson, S. (2004). Distribution of Clostridium difficile variant toxinotypes and strains with binary toxin genes among clinical isolates in an American hospital. J Med Microbiol. 53, 887-94.

Gibert, M., Marvaud, J. C., Pereira, Y., Hale, M. L., Stiles, B. G., Boquet, P., Lamaze, C., and Popoff, M. R. (2007). Differential requirement for the translocation of clostridial binary toxins: iota toxin requires a membrane potential gradient. FEBS Lett. 581, 1287-1296. 
Gülke, I., Pfeifer, G., Liese, J., Fritz, M., Hofmann, F. Aktories, K., and Barth, H. (2001). Characterization of the ADP-ribosyltransferase CDTa from Clostridium difficile by site directed mutagenesis. Infect. Immun. 69, 60046011.

Handschumacher, R.E., Harding, M.W., Rice, J., Drugge, R.J., and Speicher, D.W. (1984) Cyclophilin: a specific cytosolic binding protein for cyclosporin A. Science 226, 544-547.

Hale, M. L., Marvaud, J. C., Popoff, M. R., and Stiles, B. G. (2004). Detergent-resistant membrane microdomains facilitate Ib oligomer formation and biological activity of Clostridium perfringens iota-toxin. Infect.Immun. $\mathbf{7 2}$, 2186-2193.

Haug, G., Aktories K., and Barth H. (2004). The host cell chaperone Hsp90 is necessary for cytotoxic action of the binary iota-like toxins. Infect.Immun. 72, 3066-3068.

Haug, G., Leemhuis J., Tiemann D., Meyer D. K., Aktories K., and H. Barth. (2003). The host cell chaperone Hsp90 is essential for translocation of the binary Clostridium botulinum C2 toxin into the cytosol. J.Biol.Chem. 278, 32266-32274.

Haug, G., C. Wilde, J. Leemhuis, D. K. Meyer, Aktories K., and Barth H. (2003). Cellular uptake of Clostridium botulinum C2 toxin: membrane translocation of a fusion toxin requires unfolding of its dihydrofolate reductase domain. Biochemistry 42, 15284-15291.

Heine, K., Pust, S., Enzenmüller, S., Barth, H. (2008). ADP-ribosylation of actin by the Clostridium botulinum C2 toxin in mammalian cells results in delayed caspase-dependent apoptotic cell death. Infect. Immun.76, 4600-4608.

Hilger, H., Pust, S., von Figura, G., Kaiser, E., Stiles, B. G., Popoff, M. R., and Barth, H. (2009). The long-lived nature of clostridium perfringens iota toxin in mammalian cells induces delayed apoptosis. Infect. Immun. 77 , 5593-5601.

\section{Heinlen, L. and Ballard J. D. (2010). Clostridium difficile infection. Am.J.Med.Sci. 340, 247-252.}

Kaiser, E., Pust S., Kroll C., and Barth H. (2009). Cyclophilin A facilitates translocation of the Clostridium botulinum $\mathrm{C} 2$ toxin across membranes of acidified endosomes into the cytosol of mammalian cells. Cell Microbiol. 11, 780-795. 
Kaiser, E., Kroll, C., Ernst, K., Schwan, C., Popoff, M. R., Fischer, G., Buchner, J., Aktories, K., and Barth, H. (2011). Membrane translocation of binary actin-ADP-ribosylating toxins from Clostridium difficile and Clostridium perfringens is facilitated by Cyclophilin A and Hsp90. Infect. Immun. 79, 3913-3921.

Kaiser, E., Böhm, N., Ernst, K., Langer, S., Schwan, C., Aktories, K., Popoff, M. R., Fischer, G., and Barth, H. (2012). FK506-binding protein 51 interacts with Clostridium botulinum C2 toxin and FK506 blocks membrane translocation of the toxin in mammalian cells. Cell. Microbiol. 14, 1193-1205.

Knapp, O., Benz R., Gibert M., Marvaud J. C., and Popoff M. R.(2002). Interaction of the binding component of Clostridium perfringens iota-toxin with lipid bilayer membranes: demonstration of channel formation by the activated binding component Ib and channel block by the enzyme component Ia. J.Biol.Chem. 277, 6143-6152.

Laemmli, U. K. (1970). Cleavage of structural proteins during the assembly of the head of bacteriophage T4. Nature 227, 680-685.

Martin, H., Willey B., Low D. E., Staempfli H. R., McGeer A., Boerlin P., Mulvey M., and Weese J. S. (2008). Characterization of Clostridium difficile strains isolated from patients in Ontario, Canada, from 2004 to 2006. J.Clin.Microbiol. 46, 2999-3004.

McDonald, L. C., Killgore G. E., Thompson A., Owens, Jr., R. C, Kazakova S. V., Sambol S. P., Johnson S., and Gerding D. N. (2005). An epidemic, toxin gene-variant strain of Clostridium difficile. N.Engl.J.Med. 353, 24332441.

Miyake, M., and Ohishi, I. (1987). Response of tissue-cultured cynomolgus monkey kidney cells to botulinum C2 toxin. Microb. Pathog. 3, 279-286.

Nagahama, M., Nagayasu K., Kobayashi K., and Sakurai J. (2002). Binding component of Clostridium perfringens iota-toxin induces endocytosis in Vero cells. Infect.Immun. 70, 1909-1914.

Ohishi, I. (1983). Response of mouse intestinal loop to botulinum C2 toxin: enterotoxic activity induced by cooperation of nonlinked protein components. Infect. Immun. 40, 691-695.

Ohishi, I, and Odagiri, Y. (1984). Histopathological effect of botulinum C2 toxin on mouse intestines. Infect. Immun. 43, 54-58. 
Ohishi, I., Iwasaki M., and Sakaguchi G. (1980). Purification and characterization of two components of botulinum C2 toxin. Infect.Immun. 30, 668-673.

Ohishi, I. and Tsuyama S. (1986). ADP-ribosylation of nonmuscle actin with component I of C2 toxin. Biochem.Biophys.Res.Commun. 136, 802-806.

Papatheodorou P., Carette J.E., Bell G.W., Schwan C., Guttenberg G., Brummelkamp T.R., Aktories K. (2011). Lipolysis-stimulated lipoprotein receptor (LSR) is the host receptor for the binary toxin Clostridium difficile transferase (CDT). Proc Natl Acad Sci USA 108, 16422-16427.

Papatheodorou P., Wilczek C., Nölke T., Guttenberg G., Hornuss D., Schwan C., Aktories K. (2012). Identification of the cellular receptor of Clostridium spiroforme toxin. Infect Immun. 80, 1418-1423.

Perelle, S., Domenighini M., and Popoff M. R. (1996). Evidence that Arg-295, Glu-378, and Glu-380 are activesite residues of the ADP-ribosyltransferase activity of iota toxin. FEBS Lett. 395, 191-194.

Perelle, S., Gibert, M., Bourlioux, P., Corthier, G., Popoff, M. R. (1997a). Production of a complete binary toxin (actin-specific ADP-ribosyltransferase) by Clostridium difficile CD196. Infect. Immun. 65, 1402-1407.

Perelle, S., Scalzo S., Kochi S., Mock M., and Popoff M. R. (1997b). Immunological and functional comparison between Clostridium perfringens iota toxin, C. spiroforme toxin, and anthrax toxins. FEMS Microbiol.Lett. 146, $117-121$

Pirkl, F. and Buchner J. (2001). Functional analysis of the Hsp90-associated human peptidyl prolyl cis/trans isomerases FKBP51, FKBP52 and Cyp40. J Mol Biol. 308, 795-806.

Popoff, M. R. and Boquet, P. (1988). Clostridium spiroforme toxin is a binary toxin which ADP-ribosylates cellular actin. Biochem.Biophys.Res.Commun. 152, 1361-1368.

Popoff, M. R., Rubin, E. J., Gill, D. M., and Boquet, P. (1988). Actin-specific ADP-ribosyltransferase produced by a Clostridium difficile strain. Infect.Immun. 56, 2299-2306.

Pratt, W. B. and Toft, D. O. (1997). Steroid receptor interactions with heat shock protein and immunophilin chaperones. Endocr.Rev. 18, 306-360. 
Ratts, R., Zeng, H., Berg, E. A., Blue, C., McComb, M. E., Costello, C. E., Vanderspek, J. C. and Murphy, J. R. (2003). The cytosolic entry of diphtheria toxin catalytic domain requires a host cell cytosolic translocation factor complex. J.Cell Biol. 160, 1139-1150.

Richter, K., Soroka, J., Skalniak, L., Leskovar, A., Hessling, M., Reinstein, J., and Buchner, J. (2008). Conserved conformational changes in the ATPase cycle of human Hsp90. J.Biol.Chem. 283, 17757-17765.

Sandvig, K. and S. Olsnes. (1980). Diphtheria toxin entry into cells is facilitated by low pH. J.Cell Biol. 87, 828832.

Schering, B., Bärmann, M., Chhatwal, G. S., Geipel, U., and Aktories, K. (1988). ADP-ribosylation of skeletal muscle and non- muscle actin by Clostridium perfringens iota toxin. Eur.J.Biochem. 171, 225-229.

Schleberger, C., Hochmann, H., Barth, H., Aktories, K., and Schulz, G. E. (2006). Structure and action of the binary C2 toxin from Clostridium botulinum. J. Mol. Biol. 364, 705-715.

Schmid, A., Benz, R., Just, .I, Aktories, K. (1994). J. Biol. Chem. Interaction of Clostridium botulinum C2 toxin with lipid bilayer membranes. Formation of cation-selective channels and inhibition of channel function by chloroquine. 269, 16706-16711.

Schmid, F. X. (1993). Prolyl isomerase: enzymatic catalysis of slow protein-folding reactions. Annu.Rev.Biophys.Biomol.Struct. 22, 123-142.

Schmid, F. X., Mayr, L. M., Mucke, M., and Schonbrunner, E. R. (1993). Prolyl isomerases: role in protein folding. Adv.Protein Chem. 44, 25-66.

Sterthoff, C., Lang, A. E., Schwan, C., Tauch, A., and Aktories, K. (2010). Functional characterization of an extended binding component of the actin-ADP-ribosylating C2 toxin detected in Clostridium botulinum strain (C) 2300. Infect. Immun. 78, 1468-1474.

Schwan, C., Stecher, B., Tzivelekidis, T., van Ham, M., Rohde, M., Hardt, W. D., Wehland, J. and Aktories, K. (2009). Clostridium difficile toxin CDT induces formation of microtubule-based protrusions and increases adherence of bacteria. PLoS.Pathog. 5, e1000626.

Songer, J. G. (1996). Clostridial enteric diseases of domestic animals. Clin.Microbiol.Rev. 9, 216-234. 
Stiles, B. G., Hale, M. L., Marvaud, J. C., and Popoff, M. R. (2002). Clostridium perfringens iota toxin: characterization of the cell-associated iota b complex. Biochem.J. 367, 801-808.

Stiles, B. G., Blöcker, D., Hale, M. L., Guetthoff, M. A., and Barth, H. (2002). Clostridium botulinum C2 toxin: binding studies with fluorescence-activated cytometry. Toxicon. 40, 1135-1140.

Stiles, B. G., Hale, M. L., Marvaud, J.-C., and Popoff, M. (2000). Clostridium perfringens iota toxin: binding studies and characterization of cell surface receptor by fluorescence-activated cytometry. Infect.Immun. 68, 34753484.

Stiles, B. G. and Wilkins, T. D. (1986a). Purification and characterization of Clostridium perfringens iota toxin: dependence on two nonlinked proteins for biological activity. Infect.Immun. 54, 683-688.

Stiles, B. G. and Wilkins, T. D. (1986b). Clostridium perfringens iota toxin: Synergism between two proteins. Toxicon 24, 767-773.

Stubbs, S., Rupnik, M., Gibert, M., Brazier, J., Duerden, B., and Popoff, M. (2000). Production of actin-specific ADP-ribosyltransferase (binary toxin) by strains of Clostridium difficile. FEMS Microbiol.Lett. 186, 307-312.

Taylor, M., Navarro-Garcia, F., Huerta, J., Burress, H., Massey, S., Ireton, K., and Teter, K. (2010). Hsp90 is required for transfer of the cholera toxin A1 subunit from the endoplasmic reticulum to the cytosol. J.Biol.Chem. 285, 31261-31267.

Wegner, A. and Aktories, K. (1988). ADP-ribosylated actin caps the barbed ends of actin filaments. J.Biol.Chem. 263, 13739-13742.

Weigt, C., Just, I., Wegner, A., and Aktories, K. (1989). Nonmuscle actin ADP-ribosylated by botulinum C2 toxin caps actin filaments. FEBS Lett. 246, 181-184.

Wiegers, W., Just, I., Müller, H., Hellwig, A., Traub, P., Aktories, K. (1991). Alteration of the cytoskeleton of mammalian cells cultured in vitro by Clostridium botulinum $\mathrm{C} 2$ toxin and C3 ADP-ribosyltransferase. Eur. J. Cell Biol. 54, 237-45.

Vandekerckhove ,J., Schering, B., Bärmann, M., and Aktories, K. (1987). Clostridium perfringens iota toxin ADPribosylates skeletal muscle actin in Arg-177. FEBS Lett. 225, 48-52. 
Vandekerckhove, J., Schering, B., Bärmann, M., and Aktories, K. (1988). Botulinum C2 toxin ADP-ribosylates cytoplasmic beta/gamma-actin in arginine 177. J. Biol. Chem. 263, 696-700.

Zornetta, I., Brandi, L., Janowiak, B., Dal Molin, F., Tonello, F., Collier, R. J., and Montecucco, C. (2010). Imaging the cell entry of the anthrax oedema and lethal toxins with fluorescent protein chimeras. Cell.Microbiol.

12, 1435-1445. 


\section{Figure Legends}

Fig. 1. Effect of CsA on the intracellular distribution of the enzyme component C2I of C. botulinum C2 toxin. HeLa cells were pre-incubated for 30 min at $37{ }^{\circ} \mathrm{C}$ with $20 \mu \mathrm{M}$ CsA or $100 \mathrm{nM}$ bafilomycin A1 (BafA1) or left untreated for control. Subsequently, fluorescentlabeled C2I (500 ng/ml) plus C2IIa $(4 \mu \mathrm{g} / \mathrm{ml})$ were added and cells were further incubated for $2 \mathrm{~h}$ at $37^{\circ} \mathrm{C}$. Cells were fixed with paraformaldehyde and bright-field microscopy pictures were taken $($ scale bar $=50 \mu \mathrm{m})$. STED microscopy images $->$ Christian Osseforth Biophysik

Fig. 2. Co-precipitation of C2I with Cyp40 from lysates of $\mathrm{C} 2$ toxin-treated HeLa cells. Cells were incubated for $2 \mathrm{~h}$ at $37^{\circ} \mathrm{C}$ with C2IIa (800 ng/ml) plus either GST-C2I (400 ng/ml, A), or biotin-C2I (400 ng/ml, B), or without any protein for control (con). Cells were lysed and the cytoplasmic fraction was obtained by centrifugation. For pull-down of GST-C2I or biotinC2I, the cytoplasmic fractions were incubated with glutathione-sepharose beads (A) or streptavidin-agarose beads (B), respectively over night at $4{ }^{\circ} \mathrm{C}$. The beads were washed and precipitated proteins separated by SDS-PAGE and analyzed by Western blotting with a specific antibody against Cyp40. Comparable protein loading was confirmed by Ponceau S staining of the blot membranes.

Fig. 3. Interaction of the enzyme components of C2, CDT and iota toxins with Cyp40 in vitro. A. C2I, CDTa and Ia directly interact with Cyp40 in vitro. Purified recombinant Cyp40 (starting concentration $1 \mu \mathrm{g}$, serial dilution) was spotted onto a nitrocellulose membrane via vacuum-aspiration using the dot blot system. For negative control PBS and purified recombinant C3bot, an Rho-modifying ADP-ribosyltransferase of Clostridium botulinum (starting concentration $1 \mu \mathrm{g}$, serial dilution) were spotted. The membrane was blocked and incubated for $1 \mathrm{~h}$ with biotin-labeled C2I, CDTa, or Ia $(200 \mathrm{ng} / \mathrm{ml})$ or for control with PBST 
alone. After extensive washing, the bound proteins were detected via streptavidin-peroxidase using the ECL system. B. Enzymatically inactive C2IE387/389Q interacts with Cyp40 in vitro. Purified Cyp40 and for negative control the proteins FKB12 and C3bot, as well as PBS were spotted onto a nitrocellulose membrane (starting concentration $0.5 \mu \mathrm{g}$, serial dilution). Wild type C2I and the enzymatically inactive C2IE387/389Q (each $200 \mathrm{ng} / \mathrm{ml}$ ) were used for overlay. Bound C2I and C2IE387/389Q proteins were detected by an antibody against C2I and peroxidase-coupled secondary antibody using the ECL system. C. Binding of denatured versus native C2I, CDTa and Ia to Cyp40. For unfolding, the biotin-labeled enzyme components C2I, CDTa and Ia were incubated with $6 \mathrm{M}$ guanidine hydrochloride, $2 \mathrm{mM}$ DTT, $30 \mathrm{mM}$ TrisHCl for $1 \mathrm{~h}$ or with PBS for control. Subsequently, a nitrocellulose membrane with spotted Cyp40 (starting concentration $1 \mu \mathrm{g}$, serial dilution) and FKBP12, C3bot and PBS for negative control was probed for $1 \mathrm{~h}$ with denatured or native C2I, CDTa and Ia proteins (each $200 \mathrm{ng} / \mathrm{ml}$ ). The bound enzyme components were detected via streptavidin-peroxidase using the ECL system.

Fig. 4 ITC $\rightarrow$ Cordelia

Fig. 5. The non-immunosuppressive CsA-derivative VK112/2 delays intoxication with C2 toxin and iota toxin. A. Effect of VK112/2 on intoxication of cells with C2 toxin. Vero cells were pre-incubated for $30 \mathrm{~min}$ at $37{ }^{\circ} \mathrm{C}$ with increasing concentrations of VK112/2 and for control with $20 \mu \mathrm{M}$ Cyclosporin A (CsA). For further control, cells were left untreated (con). Subsequently, C2 toxin ( $75 \mathrm{ng} / \mathrm{ml}$ C2I plus $150 \mathrm{ng} / \mathrm{ml} \mathrm{C2IIa)} \mathrm{was} \mathrm{added} \mathrm{and} \mathrm{cells} \mathrm{were} \mathrm{further}$ incubated at $37{ }^{\circ} \mathrm{C}$. Morphological changes were monitored at the indicated time points. The pictures shown were taken after $2.25 \mathrm{~h}$. For quantitative analysis, percentage of rounded cells 
was determined from the pictures taken at the indicated time points. Values are given as mean $\pm \mathrm{SD}(\mathrm{n}=3)$. Significance was tested by using the student's t-test and values refer to samples treated with toxin only ( $\mathrm{ns}=$ not significant, $*=\mathrm{p}<0.05, * *=\mathrm{p}<0.01, * * *=\mathrm{p}<0.001)$. B. Effect of VK112/2 on intoxication of cells with iota toxin. Vero cells were treated with iota toxin (40 $\mathrm{ng} / \mathrm{ml}$ Ia plus $80 \mathrm{ng} / \mathrm{ml} \mathrm{Ib}$ ) in the presence or absence of CsA and VK112/2 exactly as described for $\mathrm{C} 2$ toxin in $\mathrm{A}$. The pictures shown were taken after $3 \mathrm{~h}$. C. Effect of the noncellpermeable CsA-derivative MM284 on intoxication of cells with C2 and iota toxin. Vero cells were treated with C2 toxin (50 ng/ml C2I plus $100 \mathrm{ng} / \mathrm{ml} \mathrm{C2IIa)} \mathrm{or} \mathrm{iota} \mathrm{toxin} \mathrm{(30} \mathrm{ng/ml} \mathrm{Ia}$ plus $60 \mathrm{ng} / \mathrm{ml} \mathrm{Ib}$ ) in the presence or absence of $500 \mu \mathrm{M}$ MM284 exactly as described in A.

Fig. 6. The non-immunosuppressive CsA-derivative VK112/2 inhibits the pH-dependent translocation of cell-bound $\mathrm{C} 2$ toxin across the cytoplasmic membrane. Vero cells were pre-incubated for 30 min at $37^{\circ} \mathrm{C}$ with $100 \mathrm{nM}$ BafA1 and VK112/2. For control, cells were treated with the non-cellpermeable CsA-derivative MM284 or left untreated. Subsequently, cells were cooled to $4{ }^{\circ} \mathrm{C}$ and C2 toxin ( $150 \mathrm{ng} / \mathrm{ml} \mathrm{C} 2 \mathrm{I}$ plus $300 \mathrm{ng} / \mathrm{ml} \mathrm{C} 2 \mathrm{IIa}$ ) was added. After 15 min at $4{ }^{\circ} \mathrm{C}$ the medium was adjusted to $\mathrm{pH} 4.6$ and the cells were incubated at $37^{\circ} \mathrm{C}$ for 10 min. Afterwards, the acidic medium was removed and cells were further incubated with FCSand BafA1-containing medium at $37{ }^{\circ} \mathrm{C}$. Toxin-induced morphological changes were monitored. The pictures shown were taken after $5.5 \mathrm{~h}($ scale bar $=100 \mu \mathrm{m})$. For quantitative analysis, percentage of rounded cells was determined from the pictures taken at the indicated time points. Values are given as mean \pm SD $(n=3)$. Significance was tested by using the student's t-test and values refer to samples treated with toxin only (ns = not significant, $* * *=\mathrm{p}<0.001)$ 
Figure 1
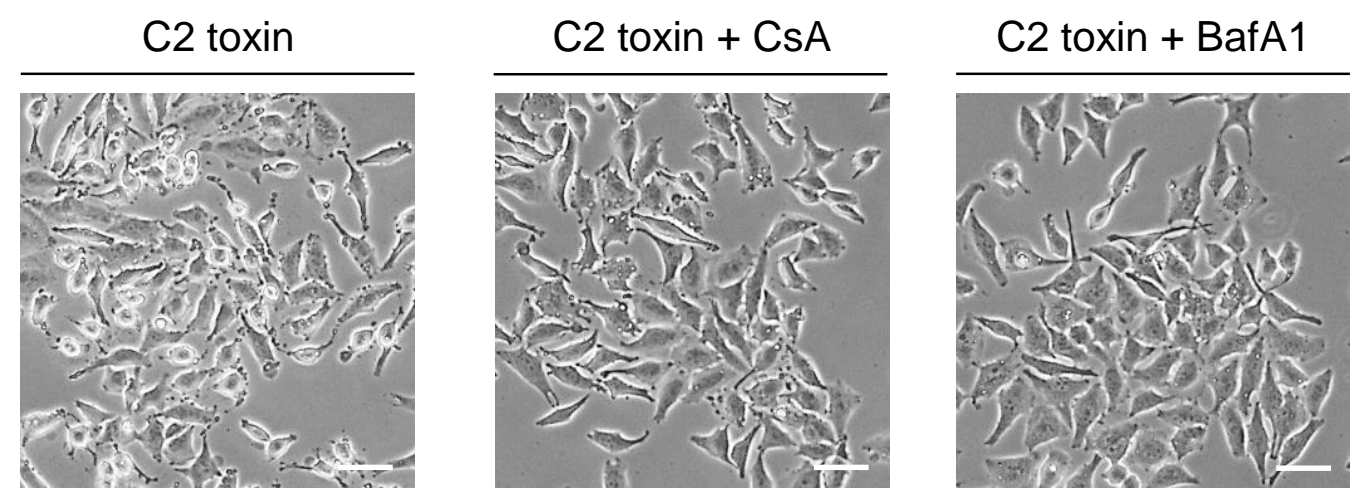

Bright-field microscopy
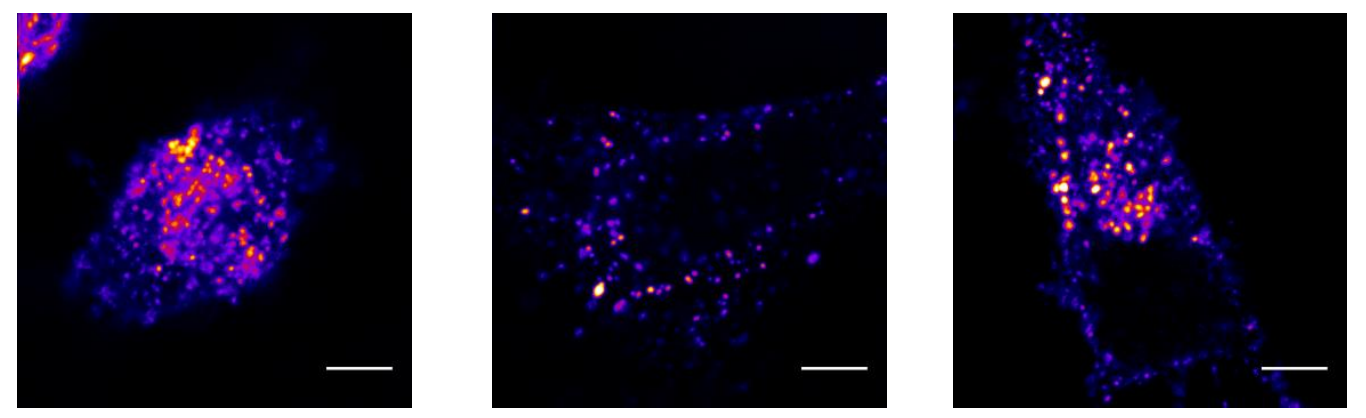

Confocal microscopy
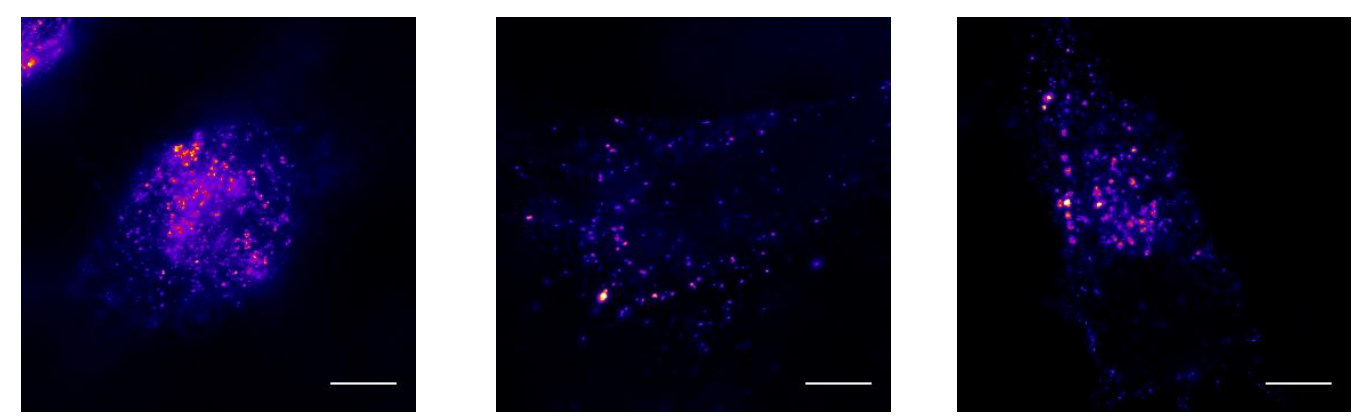

STED microscopy 
Figure 2
A
GST-C21 con
+ C2lla
$43 \mathrm{kDa}$
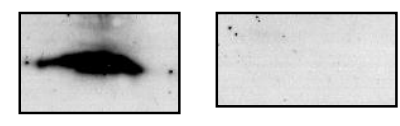
WB: anti-Cyp40
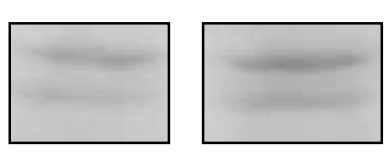
Ponceau S
B

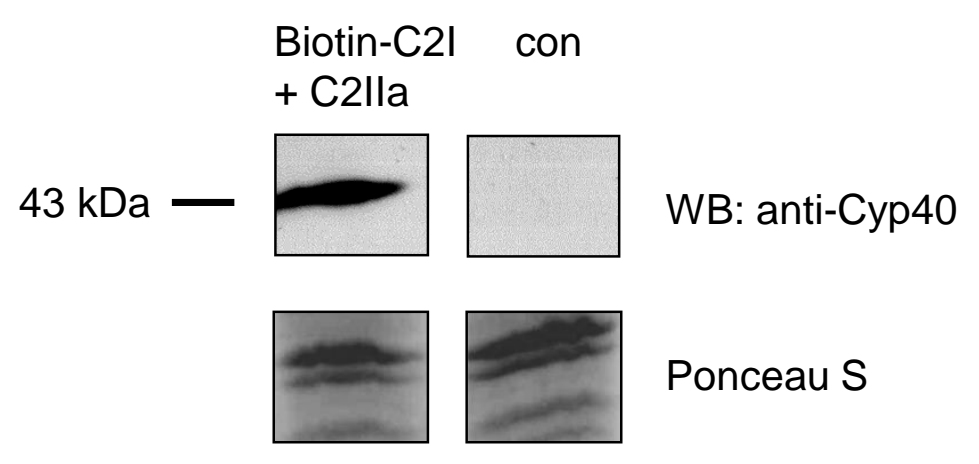


Figure 3

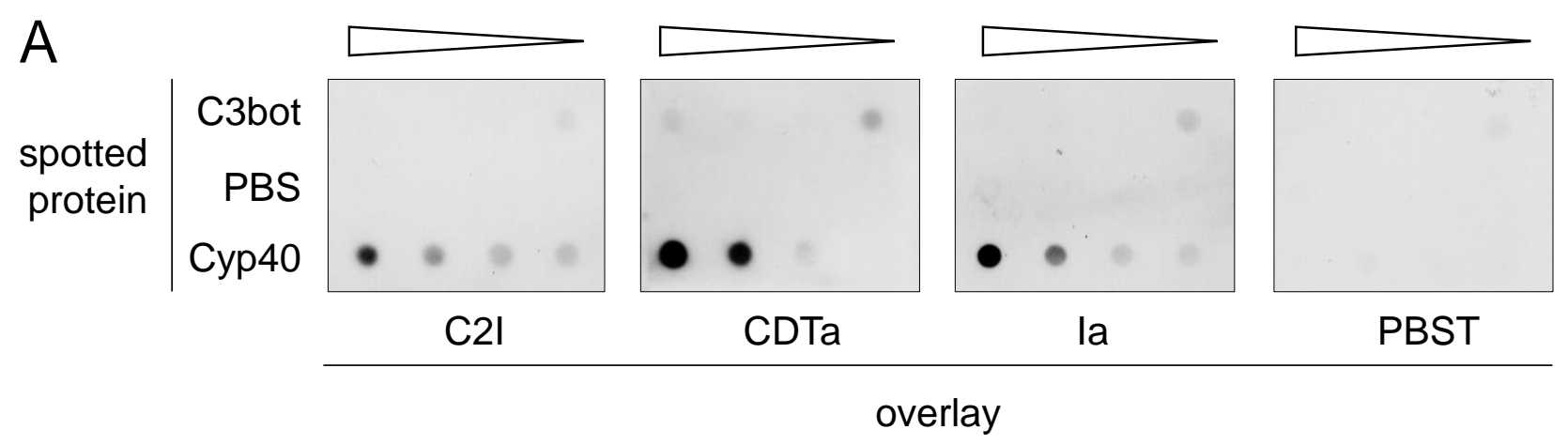

B

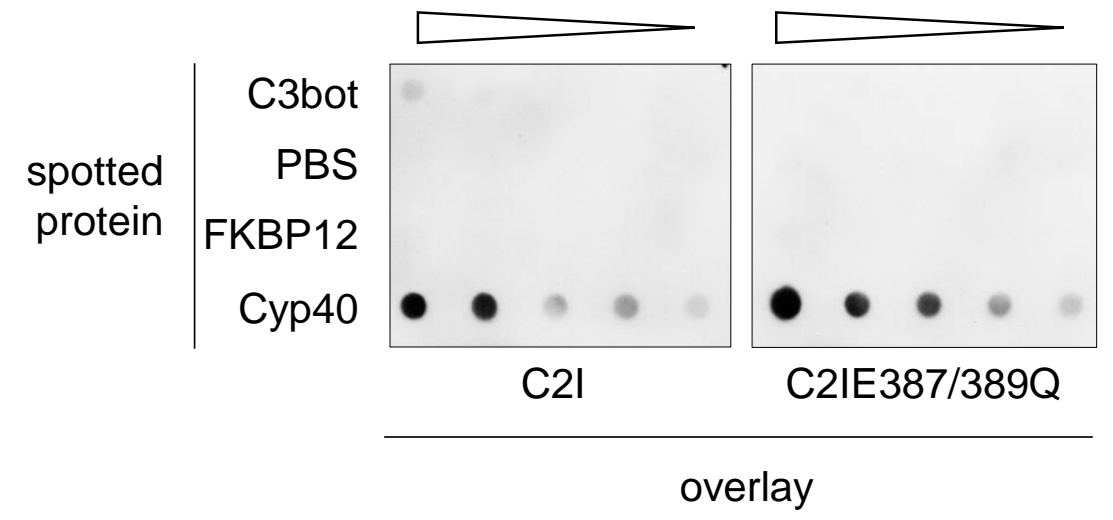

C
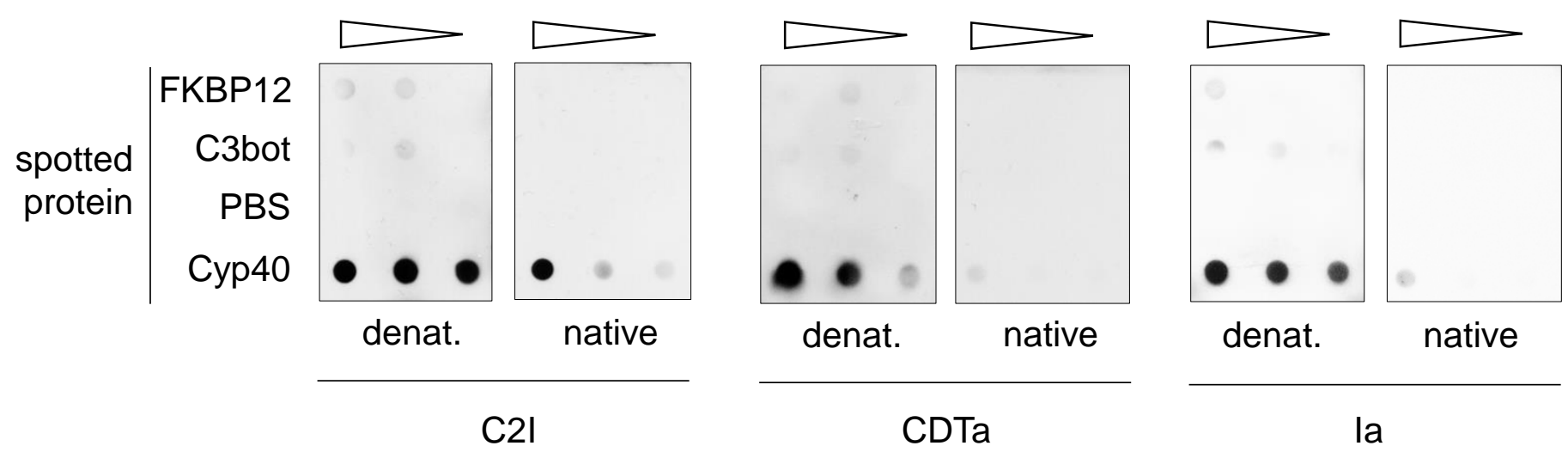
Figure 4

Time ( $\min )$

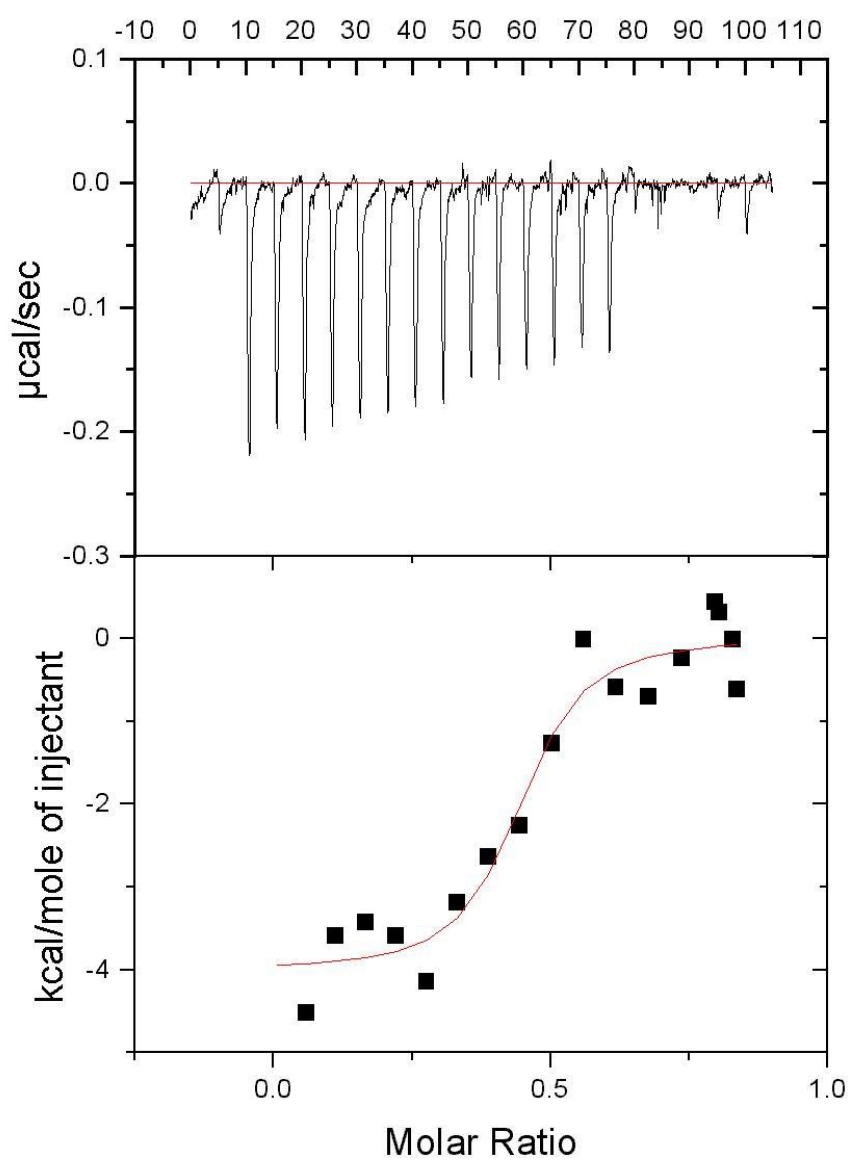

$\mathrm{N}=0.42$

$K=9.95 \times 10^{6}$

$\mathrm{DH}=-4013$

DS $=18.33$ 


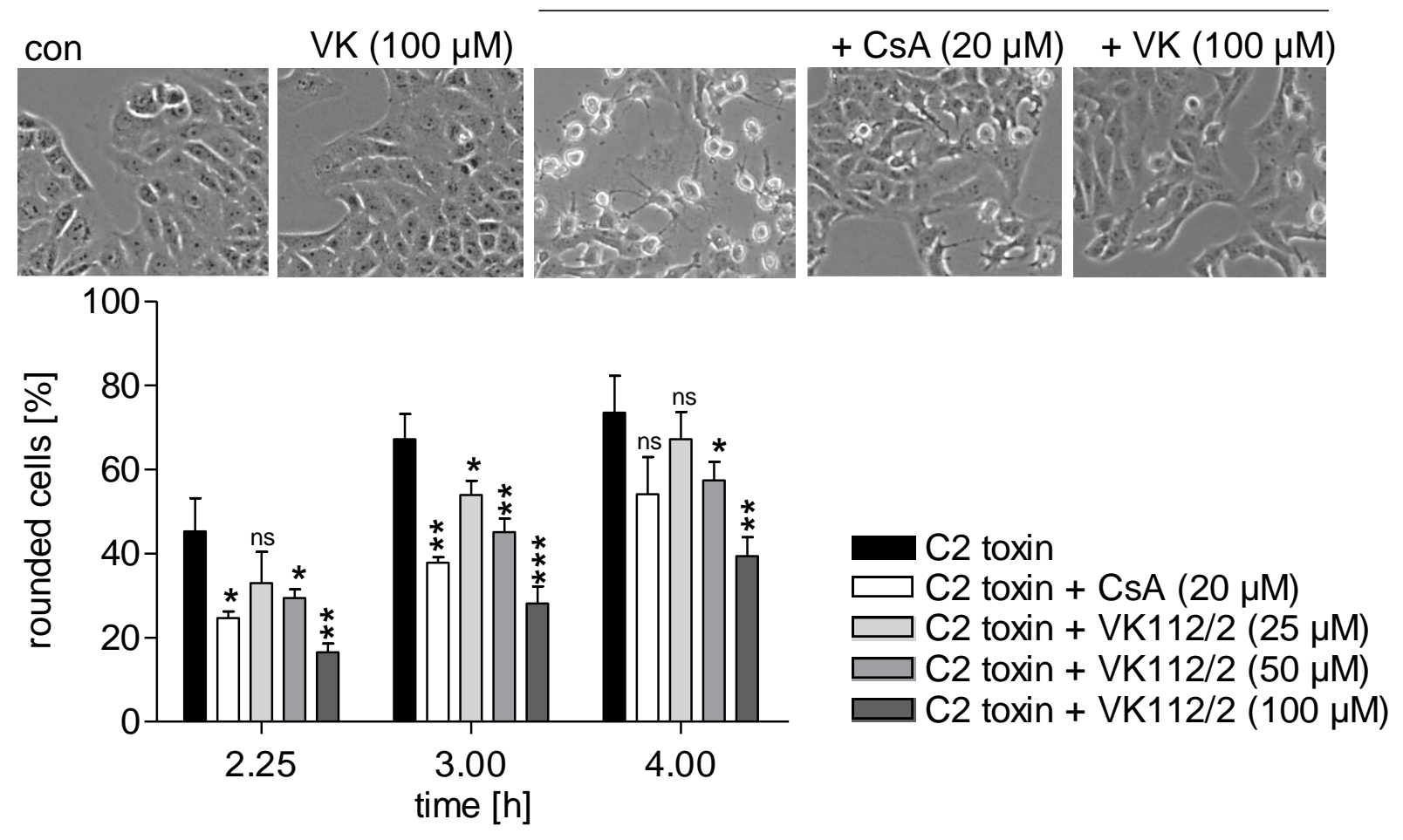

B

iota toxin
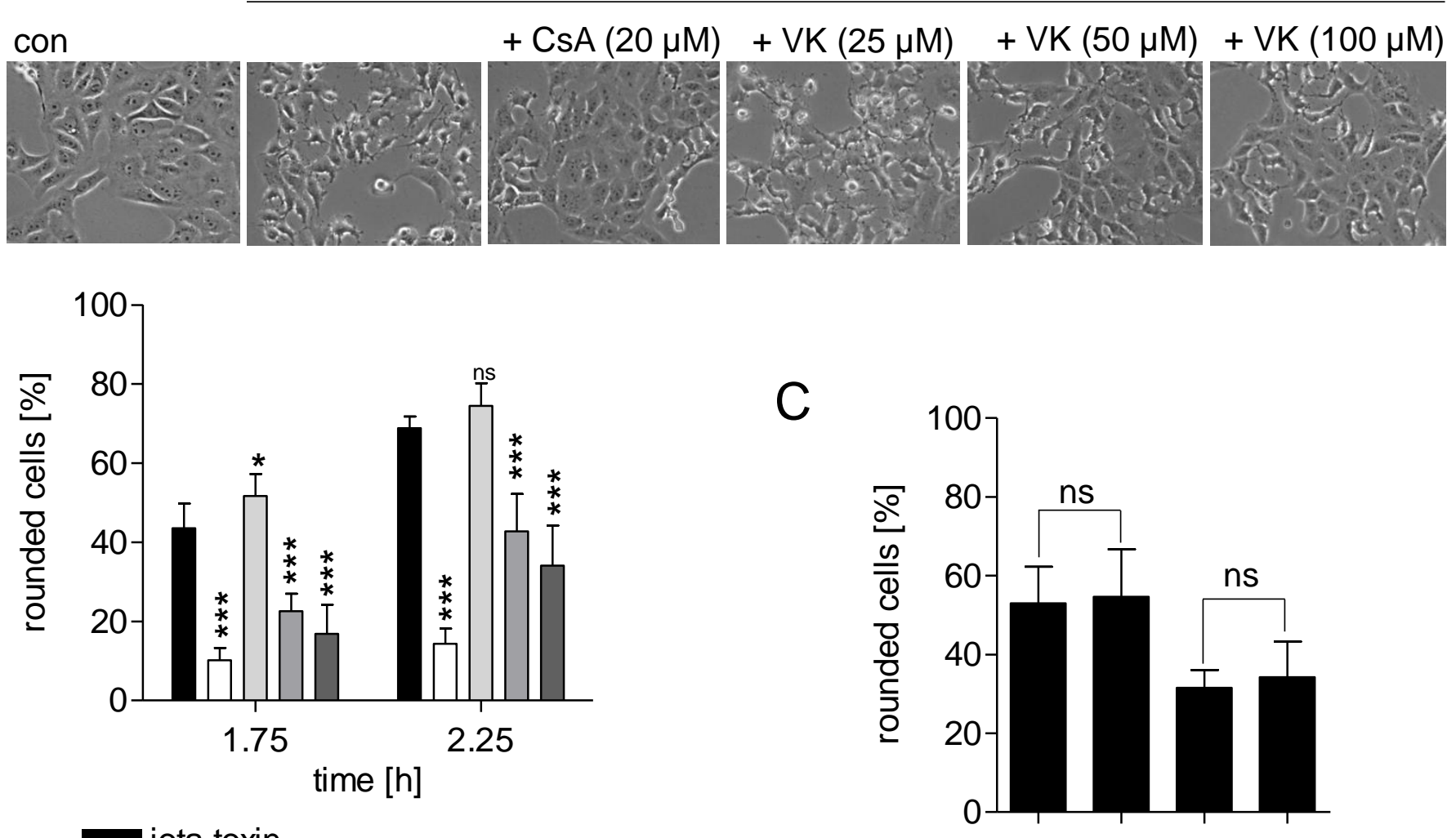

iota toxin

$\square$ iota toxin + CsA $(20 \mu \mathrm{M})$

$\square$ iota toxin + VK112/2 (25 $\mu \mathrm{M})$

$\square$ iota toxin + VK112/2 (50 $\mu \mathrm{M})$

$\square$ iota toxin + VK112/2 (100 $\mu \mathrm{M})$ 
Figure 6

C2 toxin

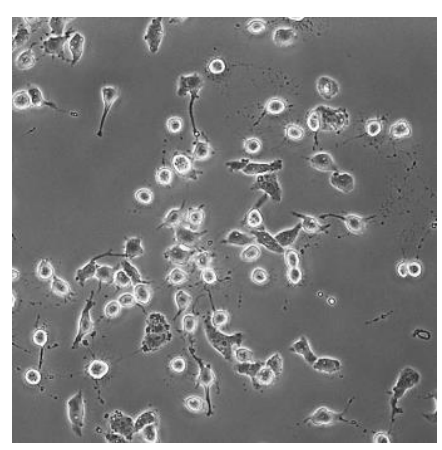

C2 toxin + DMSO

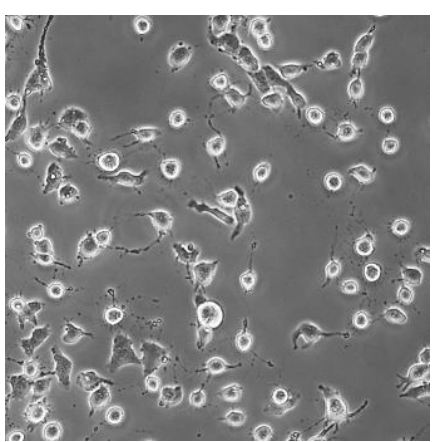

C2 toxin + VK112/2

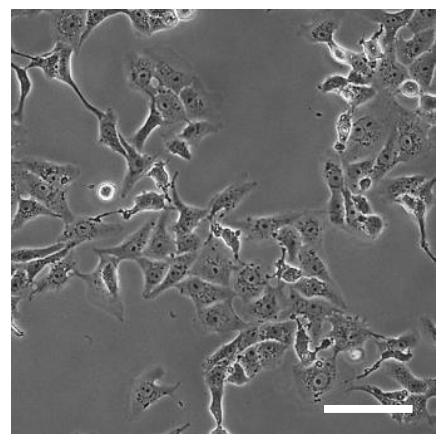

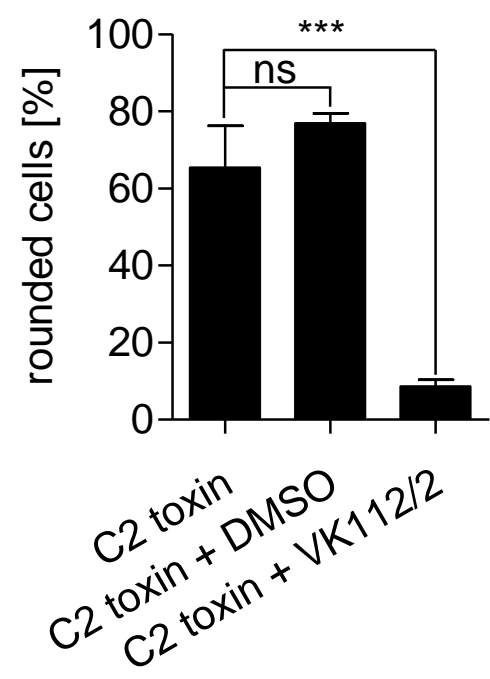

